\title{
A New Prognostic Instrument Specifically Designed for Patients Irradiated for Recurrent Carcinoma of the Bladder
}

\author{
LISA MANIG $^{1}$, STEFAN JANSSEN $^{1}$, STEVEN E SCHILD ${ }^{2}$ and DIRK RADES ${ }^{1}$ \\ ${ }^{1}$ Department of Radiation Oncology, University of Lübeck, Lübeck, Germany; \\ ${ }^{2}$ Department of Radiation Oncology, Mayo Clinic, Scottsdale, AZ, U.S.A.
}

\begin{abstract}
Background/Aim: To develop an instrument that could estimate the 1-year survival probabilities of patients irradiated for recurrent carcinoma of the bladder. Patients and Methods: Thirty patients irradiated for locally recurrent bladder carcinoma were included. Six pre-treatment factors [age, gender, Karnofsky score (KPS), pack years, grading and time between cancer diagnosis and radiotherapy] were evaluated for survival. Of those factors showing a trend or significance on multivariate analysis, 1-year survival rates were added. Results: On multivariate analysis, KPS was significant (hazard ratio $(H R)=3.76, p=0.008$ ), age showed a trend $(H R=2.04, p=0.13)$. Patient scores were five, nine, ten or fourteen points with 1-year survival rates of $13 \%$, $25 \%, 57 \%$ and $82 \%(p=0.003)$. Three groups were designed, A (5-9 points), B (10 points) and C (14 points) with 1-year survival rates of $17 \%, 57 \%$ and $82 \%(p=0.001)$. Conclusion: This score, including three groups with different 1 -year survival probabilities, can aid physicians treating patients with recurrent bladder carcinoma.
\end{abstract}

Carcinomas of the urinary bladder are uncommon compared to many other tumor entities (1). Up to more than $50 \%$ of patients develop a local recurrence following primary treatment of bladder carcinoma (1-3). In this situation, many patients receive trans-urethral resection of the recurrent tumor followed by local radiotherapy or chemo-radiation rather than radical cystectomy in order to preserve the urinary bladder (2). Generally, patients treated for recurrent malignant disease have a worse prognosis than those

This article is freely accessible online.

Correspondence to: Professor Dirk Rades, Department of Radiation Oncology, University of Lübeck, Ratzeburger Allee 160, D-23552 Lübeck, Germany. Tel: +49 4515006661, e-mail: rades.dirk@gmx.net

Key Words: Locally recurrent carcinoma of the bladder, irradiation, pre-treatment factors, predictive score, survival. receiving primary treatment. The prognoses of patients with a recurrent carcinoma of the bladder may be improved with modern systemic treatments and radiation techniques (4-7).

Another approach that has gained importance in anticancer treatment during recent years includes the personalization of the treatment (8-10). This approach aims to provide optimal treatment for single patients by considering their individual situation including personal needs and resources. When aiming to administer a personalized treatment regimen, treating physicians are also strongly recommended to take into consideration the patient's remaining survival time. Thus, it is quite important to be able to judge this time as precisely as possible before assigning the patient to a specific treatment program. In order to support physicians in this aspect, many survival scores have become available during the last decade, mainly for patients requiring irradiation for metastatic disease (11-17). However, since many patients irradiated for recurrent carcinoma of the bladder have a limited prognosis, it appears reasonable to create a survival score also for this particular group.

Therefore, this study was conducted aiming to develop exactly such a tool to support physicians when they aim to select the optimal treatment program for a patient presenting with a locally recurrent carcinoma of the bladder.

\section{Patients and Methods}

The data of 30 patients who were treated with conventional radiotherapy alone or in combination with radio-sensitizing chemotherapy for locally recurrent carcinoma of the urinary bladder were analyzed with respect to a possible relation to survival. Sixteen patients $(53 \%)$ received conventionally-fractionated radiotherapy with five times $1.8 \mathrm{~Gy}$ per week up to $59.4 \mathrm{~Gy}$ and fourteen patients additional chemotherapy. Pre-treatment factors included in the survival analyses were age, gender, Karnofsky score (KPS), number of pack years, grading of the recurrent tumor and time between cancer diagnosis and radiotherapy of the locally recurrent tumor (Table I).

Survival analyses were conducted with the Kaplan-Meier analysis plus the log-rank test. The pre-treatment factors achieving significance on these analyses $(p<0.05)$ were additionally analyzed for independent associations with survival with the Cox 
proportional hazards model. Factors that showed at least a trend $(p<0.15)$ were used for the predictive score. One-year survival rates of these factors given in percent were divided by 10 (factor scores). To calculate a patient's survival score, the factor scores were summed up. Higher scores were associated with better 1-year survival rates.

\section{Results}

Two of the evaluated six pre-treatment factors, patient age and KPS, showed significant relations to survival on univariate analyses (Table I). On the additional multivariate analysis, the KPS was also significant (hazard $\operatorname{ratio}(\mathrm{HR})=3.76,95 \%$ confidence interval $(\mathrm{CI})=1.42-10.42, p=0.008)$, and age showed a trend $(\mathrm{HR}=2.04,95 \% \mathrm{CI}=0.81-5.41, p=0.13)$. Therefore, both factors were used in the scoring tool.

Based on 1-year survival rates, the scoring points obtained for age were 3 points (age $\leq 76$ years) and 7 points (age $\geq 77$ years), respectively. And the scoring points for the KPS were 2 points (KPS $\leq 70$ ) and 7 points (KPS $>70$ ), respectively. Thus, patients' survival scores were $5,9,10$ or 14 points. The corresponding 1-year survival rates were $13 \%, 25 \%, 57 \%$ and $82 \%$, respectively ( $p=0.003$, Figure 1$)$. Corresponding median survival times were 6.5 months, 5 months, 18 months and $>80$ months (median not reached during the follow-up period of more than 80 months), respectively.

Taking into account these survival data, 5 and 9 points were combined to one prognostic group as their median survivals were similar. Thus, three prognostic groups were designed, group A (5-9 points), group B (10 points) and group C (14 points), with 1 -year survival rates of $17 \%, 57 \%$ and $82 \%$, respectively ( $p=0.001$, Figure 2 ). The corresponding median survival times were 5.5 months, 18 months and $>80$ months (median not reached during follow-up period), respectively.

\section{Discussion}

To be able to provide the best possible treatment program for an individual patient with recurrent carcinoma of the bladder, it is crucial to have a precise estimate of the patient's remaining lifespan. In patients with a short remaining time, a long program of treatment and aggressive approaches should likely be avoided. In patients identified as long-term survivors, the risk of treatment-related late morbidity gains importance. When patients are assigned to radiotherapy, this means that long-term survivors appear better treated with lower doses per fraction, because the risk of late morbidity has been reported to be greater with higher doses per fraction. Moreover, radiotherapy with higher total doses often results in better outcomes in terms of local disease control and survival, which has been reported for different situation such as metastases to the brain (18-20). Therefore, when aiming to deliver personalized cancer treatment, one should include the corresponding patient's survival prognosis
Table I. Univariate survival analyses of the six evaluated pre-treatment factors.

At 6 At 1 At $2 p$-Value months year years

\begin{tabular}{|c|c|c|c|c|}
\hline \multicolumn{5}{|l|}{ Age } \\
\hline$\leq 76$ Years $(\mathrm{N}=15)$ & 73 & 67 & 60 & \\
\hline$\geq 77$ Years $(\mathrm{N}=15)$ & 60 & 33 & 13 & 0.02 \\
\hline \multicolumn{5}{|l|}{ Gender } \\
\hline Female $(\mathrm{N}=5)$ & 80 & 40 & 40 & \\
\hline Male $(\mathrm{N}=25)$ & 64 & 36 & 27 & 0.44 \\
\hline \multicolumn{5}{|l|}{ Karnofsky score (KPS) } \\
\hline$\leq 70(\mathrm{~N}=12)$ & 42 & 17 & 8 & \\
\hline$>70(\mathrm{~N}=18)$ & 83 & 72 & 56 & $<0.001$ \\
\hline \multicolumn{5}{|l|}{ Number of pack years } \\
\hline$\leq 40$ Years $(\mathrm{N}=24)$ & 71 & 58 & 42 & \\
\hline$>40$ Years $(\mathrm{N}=6)$ & 50 & 17 & 17 & 0.26 \\
\hline \multicolumn{5}{|l|}{ Grading of the tumor } \\
\hline Grade $2(\mathrm{~N}=4)$ & 75 & 50 & 50 & \\
\hline Grade $3(\mathrm{~N}=26)$ & 65 & 50 & 35 & 0.42 \\
\hline \multicolumn{5}{|c|}{$\begin{array}{l}\text { Time between cancer diagnosis and } \\
\text { radiotherapy of locally recurrent tumor }\end{array}$} \\
\hline$\leq 21$ Months $(\mathrm{N}=15)$ & 67 & 47 & 40 & \\
\hline$\geq 22$ Months $(\mathrm{N}=15)$ & 67 & 53 & 33 & 0.85 \\
\hline
\end{tabular}

Bold values represent significant $p$-values.

in the decision process. This applies also to patients with a locally recurrent carcinoma of the bladder. Like for other cancer types and situations, a scoring tool for estimating the survival time of the patient to be treated would be beneficial to aid in decisions regarding treatment personalization. The present study was conducted to create such a tool. On multivariate analysis, two pre-treatment factors, age and KPS, showed a trend or significant association regarding 1year survival. Based on these factors, a scoring tool including three prognostic groups with significantly different survival rates was prepared. Patients who achieved 5 or 9 points (group A) had the worst 1-year survival probability, which was only $17 \%$. In these patients, higher-dose longercourse programs may be overly aggressive and their administration should be very carefully considered. Patients of group B (10 points) had an intermediate prognosis. Longer-course radiotherapy programs with higher total doses and lower doses per fraction appear reasonable. Group C patients (14 points) had the most favorable prognosis with a 1 -year survival probability of $82 \%$. These patients should definitively be treated with higher-dose longer-course programs. The results of radiotherapy of locally recurrent carcinoma of the bladder may be improved with addition of concurrent chemotherapy analogous to primary bladderpreserving treatment (2-4). There is a hope that combinations of radiotherapy and new systemic treatments may provide better results $(5-7,21,22)$. 


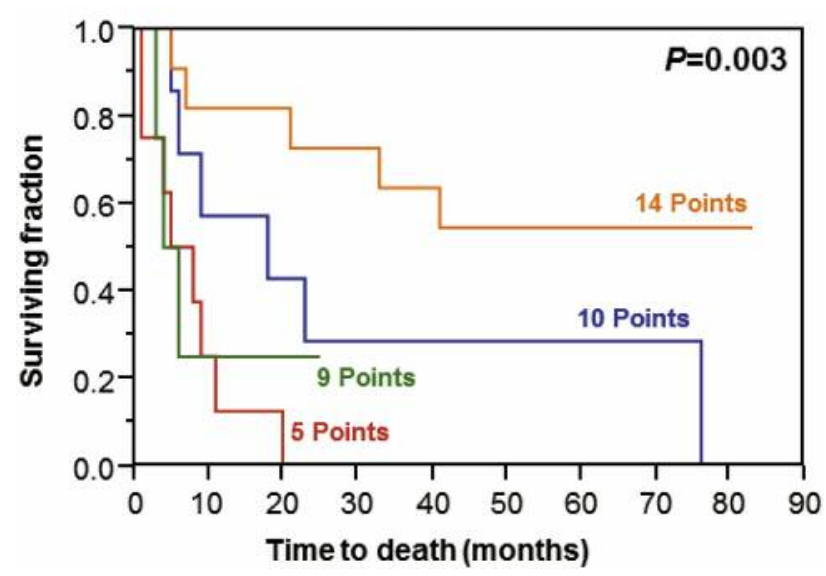

Figure 1. Kaplan-Meier curves of the different patient scores.

In conclusion, this scoring tool, which is based on pretreatment factors and includes three prognostic groups with different 1-year survival probabilities, can aid physicians who are treating patients with locally recurrent carcinoma of the urinary bladder.

\section{References}

1 Jemal A, Siegel R, Ward E, Murray T, Xu J, Smigal C and Thun M: Cancer statistics, 2006. CA: a cancer journal for clinicians 56: 106-130, 2006.

2 Rodel C, Grabenbauer GG, Kühn R, Papadopoulos T, Dunst J, Meyer M, Schrott KM and Sauer R: Combined-modality treatment and selective organ preservation in invasive bladder cancer: long-term results. J Clin Oncol 20: 3061-3071, 2002.

3 Koga $\mathrm{F}$ and Kihara K: Selective bladder preservation with curative intent for muscle-invasive bladder cancer: a contemporary review. Int J Urol 19: 388-401, 2012.

4 Weiss C, Wittlinger M, Engehausen DG, Krause FS, Ott OJ, Dunst J, Sauer R and Rodel C: Management of superficial recurrences in an irradiated bladder after combined-modality organ-preserving therapy. Int J Radiat Oncol Biol Phys 70: 1502-1506, 2008.

5 Jana BR and Zhou Y: Novel molecular targets for the therapy of urothelial cancer. Anticancer Res 35: 4557-4567, 2015.

6 Lea MA, Guzman Y and Desbordes C: Inhibition of growth by combined treatment with inhibitors of lactate dehydrogenase and either phenformin or inhibitors of 6-phosphofructo-2-kinase/ fructose-2,6-bisphosphatase 3. Anticancer Res 36: 1479-1488, 2016.

7 Kuo JH, Shih TY, Lin JP, Lai KC, Lin ML, Yang MD and Chung JG: Cantharidin induces DNA damage and inhibits DNA repairassociated protein expressions in TSGH8301 human bladder cancer cell. Anticancer Res 35: 795-804, 2015.

8 Rades D, Schild SE, Bajrovic A, Janssen S and Bartscht T: In vivo personalized radiotherapeutic approaches for elderly patients with epidural cord compression from gastric cancer. In Vivo 30: 69-72, 2016.

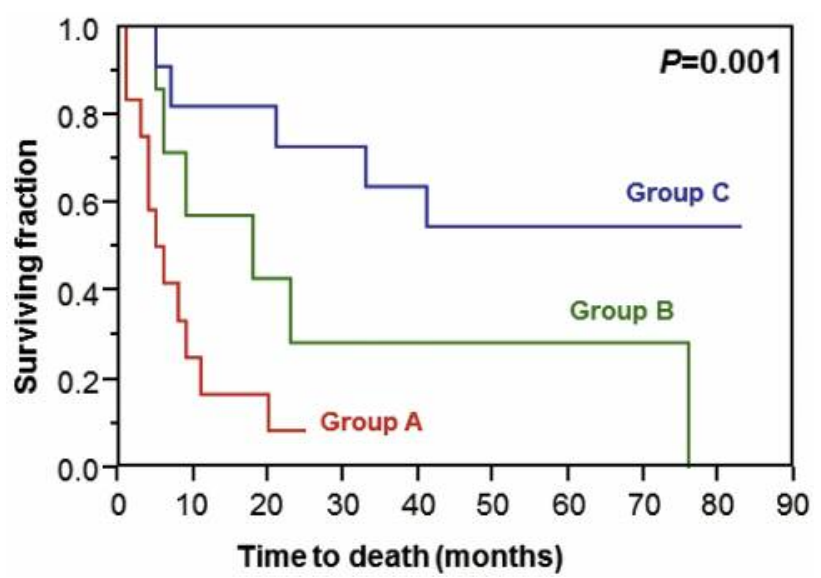

Figure 2. Kaplan-Meier curves of the survival groups A (5-9 points), $B$ (10 points) and C (14 points).

9 Seidl D, Janssen S, Strojan P, Bajrovic A, Schild SE and Rades D: Prognostic factors after definitive radio(chemo)therapy of locally advanced head and neck cancer. Anticancer Res 36: 2523-2526, 2016.

10 Kaesmann L, Janssen S, Schild SE and Rades D: Value of comorbidity scales for predicting survival after radiochemotherapy of small cell lung cancer. Lung 194: 295-298, 2016.

11 Rades D, Käsmann L, Schild SE and Janssen S: A survival score for patients receiving palliative irradiation for locally advanced lung cancer. Clin Lung Cancer 17: 558-562, 2016.

12 Douglas S, Schild SE and Rades D: A new score predicting the survival of patients with spinal cord compression from myeloma. BMC Cancer 12: 425, 2012.

13 Dziggel L, Segedin B, Podvrsnik NH, Oblak I, Schild SE and Rades D: Validation of a survival score for patients treated with whole-brain radiotherapy for brain metastases. Strahlenther Onkol 189: 364-366, 2013.

14 Rades D, Hueppe M and Schild SE: A score to identify patients with metastatic spinal cord compression who may be candidates for best supportive care. Cancer 119: 897-903, 2013.

15 Rades D, Dziggel L, Nagy V, Segedin B, Lohynska R, Veninga T, Khoa MT, Trang NT and Schild SE: A new survival score for patients with brain metastases who received whole-brain radiotherapy (WBRT) alone. Radiother Oncol 108: 123-127, 2013.

16 Bolm L, Janssen S, Käsmann L, Wellner U, Bartscht T, Schild SE and Rades D: Predicting survival after irradiation of metastases from pancreatic cancer. Anticancer Res 35: 4105-4108, 2015.

17 Janssen S, Dahlke M, Trang NT, Khoa MT and Rades D: Estimation of the six-month survival probability after radiosurgery for brain metastases from kidney vancer. Anticancer Res 35: 4215-4217, 2015.

18 Rades D, Huttenlocher S, Gebauer N, Hornung D, Trang NT, Khoa MT and Schild SE: Impact of stereotactic radiosurgery dose on control of cerebral metastases from renal cell carcinoma. Anticancer Res 35: 3571-3574, 2015.

19 Rades D, Panzner A, Dziggel L, Haatanen T, Lohynska R and Schild SE: Dose-escalation of whole-brain radiotherapy for brain 
metastasis in patients with a favorable survival prognosis. Cancer 118: 3853-3859, 2012.

20 Rades D, Huttenlocher S, Rudat V, Hornung D, Blanck O, Phuong PC, Khoa MT, Schild SE and Fischer D: Radiosurgery with 20 Gy provides better local contol of 1-3 brain metastases from breast cancer than with lower doses. Anticancer Res 35: 333-336, 2015.

21 Kilari D, Iczkowski KA, Pandya C, Robin AJ, Messing EM, Guancial E and Kim ES: Copper transporter-CTR1 expression and pathological outcomes in platinum-treated muscle-invasive bladder cancer patients. Anticancer Res 36: 495-501, 2016.
22 Nakagawa YU, Nagaya H, Miyata T, Wada Y, Oyama T and Gotoh A: Piperazine-based alpha-1 AR blocker, naftopidil, selectively suppresses malignant human bladder cells via induction of apoptosis. Anticancer Res 36: 1563-1570, 2016.

Received January 17, 2017

Revised February 25, 2017

Accepted March 1, 2017 